\title{
Groundwater Level Fluctuations Study for Coimbatore Corporation using GIS
}

\author{
Elangovan. $\mathrm{K}^{2}$ \\ \{ ela.civil@psgtech.ac.in $\left.{ }^{1}\right\}$ \\ 1Assistant Professor, Department of Civil Engineering, Mahendra Engineering College, Namakkal, \\ Pin-637 503, Tamilnadu, India, 2Professr, Department of Civil Engineering, PSG College of \\ Technology, Coimbatore, Pin-641 004, Tamilnadu, India
}

\begin{abstract}
The Current research focuses on the groundwater table evaluation for the management of groundwater resources for theutilization of drinking, domestic usage, agricultural activities and amount of subsurface water available. The research paper deals with water table identification in various locations to understand the availability of groundwater in the study area and also for the demand of water supply, due to population growth and rapid development of industries and urbanized area. The groundwater level fluctuation depends upon climate change,rainfall and soil permeation capacity. To understand the groundwater level variations in the study area, spatial distribution maps are generated by using the GIS software and it is prepared for four seasons namely winter, summer, southwest and northeast monsoon seasons. The spatial distribution maps show that southern region of the study area receives shallow water table less than $10 \mathrm{~m}$ because of majority of wetlands are located in this region so this area is bestowed with shallow water table level. In winter season spatial distribution map shows that the shallow water table level falls less than $10 \mathrm{~m}$ comprising the area 24.09 sq.km. The spatial distribution map for northeast monsoon season shows the shallow water table covers an area 21.44 sq.km. The annual average groundwater level map shows that shallow water table covers an area of $14.03 \mathrm{sq} . \mathrm{km}$ and moderate water table level comprises 108.92 sq.km. The moderate groundwater table level extends from south to south east zone. The total study area is 257.07 sq.km, out of this 24.09 sq.km i.e $9.3 \%$ have shallow groundwater table level and 117.8 sq.km have moderate water table level i.e $45.82 \%$ falls in this area during the winter season. In this analysis the shallow water table level is located in the southern part, so the resource management can be effectively done in region.
\end{abstract}

Keywords: Groundwater level, GIS- spatial distribution Map, Coimbatore Corporation, Seasons..

\section{Introduction}

The groundwater is the most important resources for the human use and agricultural activities. The resource management has a prime role for the assessment of groundwater level and quantity of water., 2, 3.The subsurface water level fluctuations can be understood by the spatial distribution map, ${ }^{4}$. This study gives an idea for providing the water harvesting structures where the water having deeper zone and also the water resourcemanagement has done effectively ${ }^{5}$. GIS provides spatial information to understand the groundwater table level 
in the study region ${ }^{6}$. The groundwater table level spatial distributions maps are generated for season wise. . $^{7}$

\section{Study Area}

The study area selected for this research is Coimbatore Corporation. The figure-1 shows the study area. It is geographically located at Lat N $10^{\circ} 54^{\prime} 45^{\prime \prime}$ and $11^{\circ} 6^{\prime} 12^{\prime \prime}$ and long E 76 $52^{\prime} 14^{\prime \prime}$ and $77^{\circ} 3^{\prime} 52^{\prime}$ '. Coimbatore is the developing city in Tamilnadu, because of Industrial hub and high density urbanized area; the water scarcity is inflated in this region. Therefore the corporation limit was selected for this research work,based on the results the proper utilization of groundwater can be done effectively.

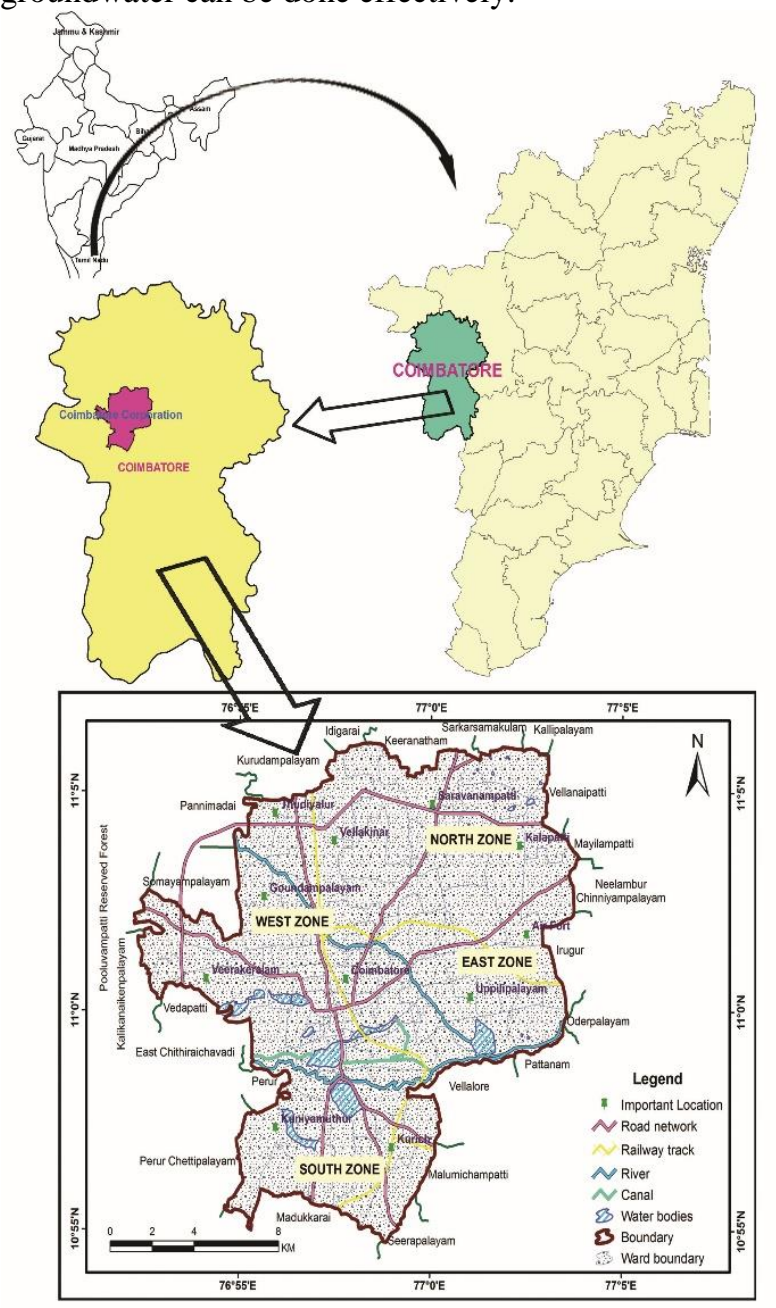

Figure-1: Coimbatore Corporation Map 


\section{Materials and Methodology}

The seven open well systems are identified in and around the study region. The water level data are obtained from Public Work Department (PWD) and Central Groundwater Board (CGWB) to study the water level variations for the period of time 2005-2014. The Arc-GIS software is incorporated for preparing the various spatial distribution maps to understand the water table fluctuations. ${ }^{9,10,11}$

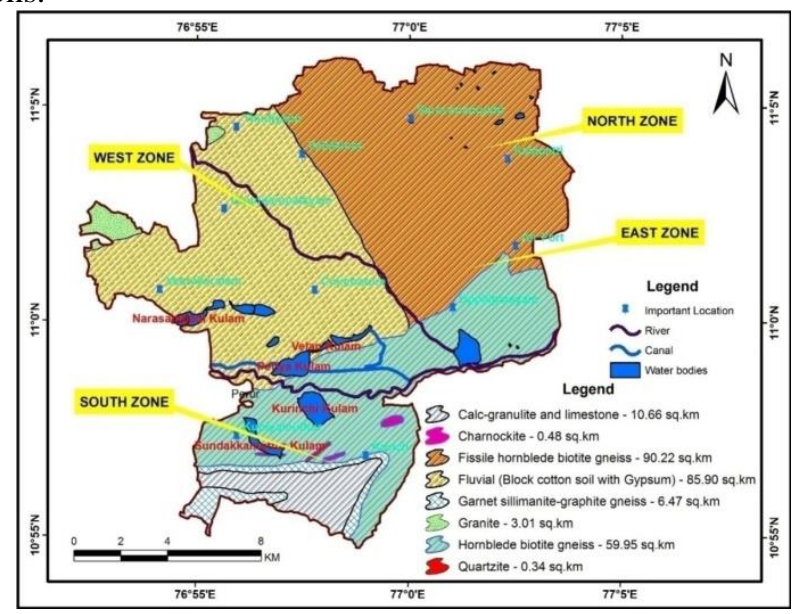

\section{Geology of Study Area}

Figure-2: Geology Spatial Map

Geological characteristics of study area emphasis the occurrence of groundwater, ${ }^{12}$ in this current study the geology map used to interpret the availability of groundwater the spatial distribution map figure- 2 shows that 90.22 sq. $\mathrm{km}$ of area is covered under Fissile hornblende biotitegenesis rock in the northern portion of the study area, where as in the southern region the hornblende biotitegenesis rock, calc-granulite and limestone rock possess the good source of groundwater zone because of the high porous in nature ${ }^{13,14,15}$, The remaining portion of the study area is enveloped with fluvial rock small portions of charnockite and meager of quartzite rock.

\section{Groundwater Table Analysis- Year Wise}

The year wise water table level is calculated and tabulated in table-1, it shows that the shallow water table level was noticed in the year of 2007 and deepest water table was noticed in the year of 2011 .

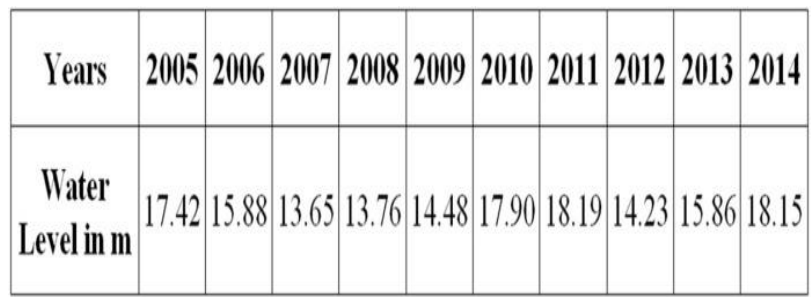

Table-1: Yearly water table data (2004 to 2014)

The precipitation was highest in the year of 2011 and it was noticed that the groundwater table increased to the shallow depth in the year of 2012.There is a very good relationship between the rainfall and groundwater table level which is shown in the figure-3. 


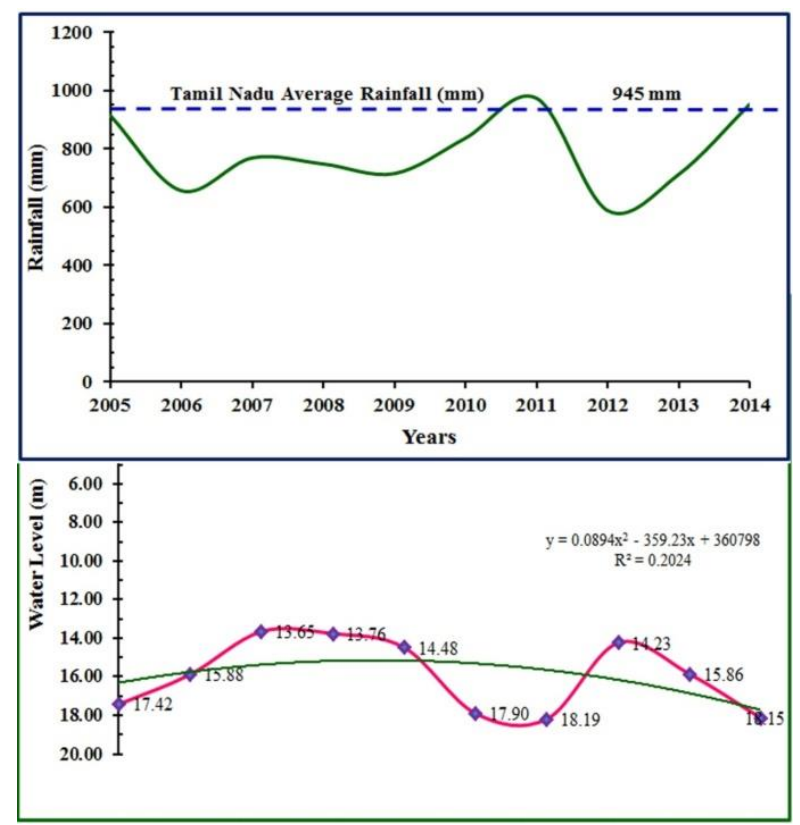

Figure-3: Precipitation and Water table comparison.

Based on the groundwater level data for the various locations in the study area, the kuruchi area is nourished with shallow water table level compared to other regions. The table$2 \&$ figure-2 shows the change in the water table level over a period from 2005 to 2014.

\begin{tabular}{|c|c|c|c|c|c|c|c|c|c|c|}
\hline $\begin{array}{c}\text { Observation Well } \\
\text { Locations }\end{array}$ & 2005 & 2006 & 2007 & 2008 & 2009 & 2010 & 2011 & 2012 & 2013 & 2014 \\
\hline Coimbatore north & 25.54 & 26.86 & 16.69 & 17.02 & 22.27 & 31.29 & 31.80 & 17.13 & 14.16 & 16.30 \\
\hline P.N.Palayam & 22.37 & 18.12 & 17.33 & 17.10 & 19.30 & 22.84 & 24.08 & 23.45 & 31.07 & 31.47 \\
\hline Anakatti & 11.46 & 6.44 & 7.65 & 8.92 & 10.84 & 16.05 & 16.46 & 6.85 & 7.03 & 11.74 \\
\hline Sugunapuram & 14.95 & 14.60 & 12.72 & 11.27 & 10.41 & 15.05 & 14.46 & 14.07 & 12.88 & 15.64 \\
\hline Kuruchi & 11.01 & 10.44 & 8.95 & 9.19 & 7.78 & 8.76 & 7.00 & 7.05 & 8.70 & 10.07 \\
\hline Pichanur & 8.32 & 5.59 & 5.20 & 4.76 & 3.71 & 4.10 & 2.94 & 3.36 & 5.06 & 5.93 \\
\hline Natchipalayam & 28.28 & 29.12 & 27.01 & 28.07 & 27.08 & 27.22 & 30.56 & 27.72 & 32.10 & 35.89 \\
\hline
\end{tabular}

Table-2: Observation well data in $\mathrm{m}$ bgl (2004 to 2014. 


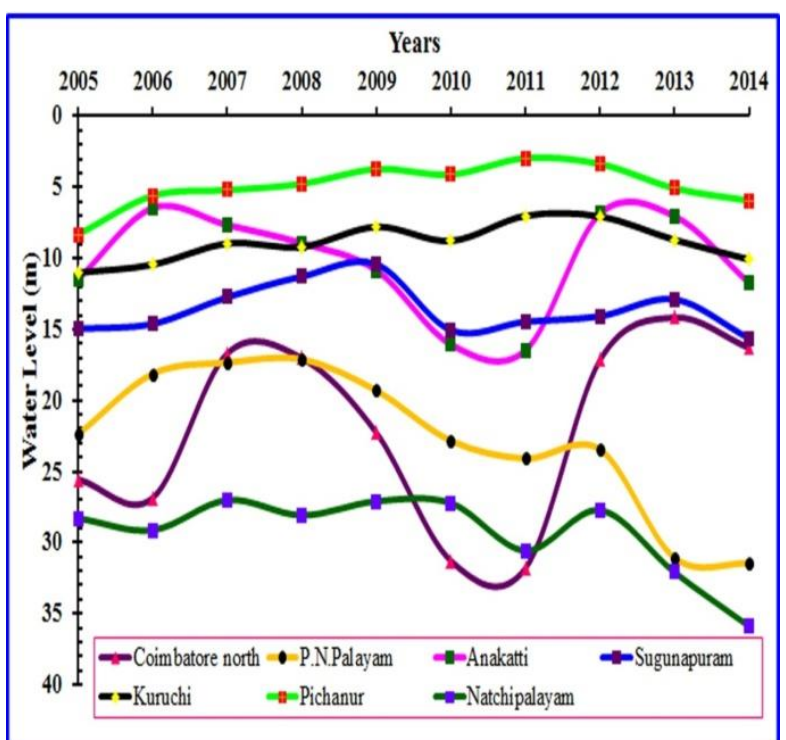

Figure-4: Observation Well Location graph in $\mathrm{m}$ bgl (2004 to 2014)

\section{Seasonal water level Analysis}

The water level data are segregated and formulated on season wise viz, winter, summer, southwest and northeast and annual average was calculated. The inference on this analysis is shown in table-3 \& figure- 4 . That the water table level moves on increasing trend during the northeast monsoon and extends upto winter season because of the rainfall impact. On other hand, the water table level turned down in southwest and summer season since the water demand was more during this season.

\begin{tabular}{|l|c|c|c|c|c|}
\hline $\begin{array}{c}\text { Observation Well } \\
\text { Locations }\end{array}$ & Winter & Summer & Southwest & Northeast & $\begin{array}{c}\text { Annual } \\
\text { Average }\end{array}$ \\
\hline Coimbatore north & 22.46 & 21.66 & 22.45 & 21.06 & 21.91 \\
\hline P.N.Palavam & 19.54 & 22.62 & 24.63 & 22.36 & 22.29 \\
\hline Anakatti & 8.77 & 9.44 & 11.88 & 10.26 & 10.09 \\
\hline Sugunapuram & 13.00 & 14.53 & 14.11 & 12.42 & 13.51 \\
\hline Kuruchi & 7.87 & 9.85 & 9.26 & 8.14 & 8.78 \\
\hline Pichanur & 4.25 & 4.86 & 5.34 & 4.77 & 4.81 \\
\hline Natchipalavam & 28.47 & 29.17 & 29.89 & 29.22 & 29.19 \\
\hline
\end{tabular}

Table-3: Seasonal water table data for Observation well in $\mathbf{m ~ b g l ~}$ 


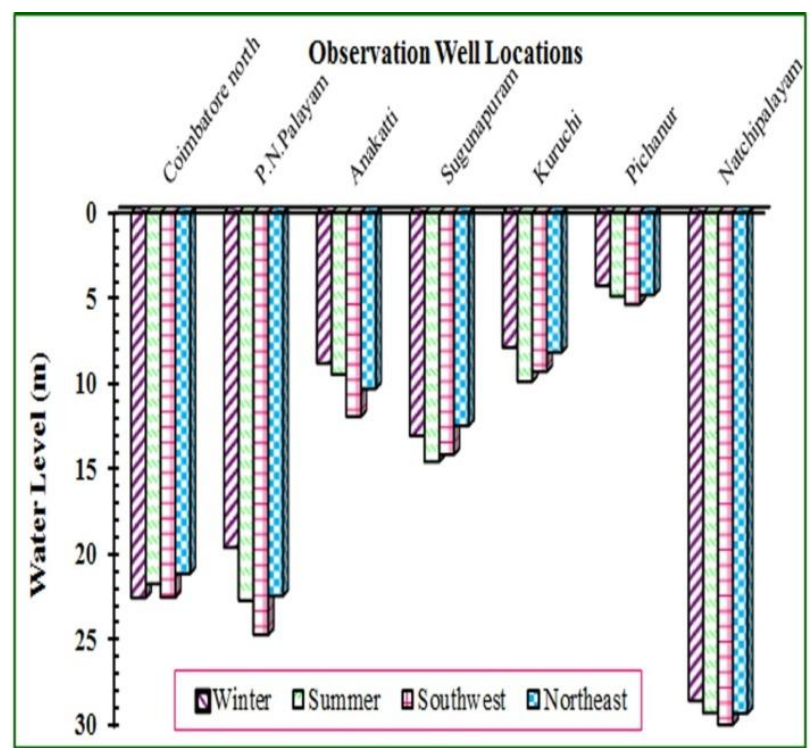

Figure-3: Seasonal water table graph for Observation well in $\mathbf{m}$ bgl.

\section{Spatial Distribution Study}

The spatial distribution map is used to understand the groundwater level in the study region. The seasonal variation of groundwater level is also studied using this map; it provides an idea about the depth of water table level available in the study boundary. If the depth of water is too deep, the artificial recharge sites can be introduced to replenish the groundwater resources.The seasonal changes viz., pre-monsoon and post-monsoon in groundwater level is also studied by using the spatial distribution map.

The categorization of groundwater is inculcated by quartile statistical method. The four groups of groundwater is classified as, shallow groundwater depth, moderate groundwater depth, deeper depth and very deeper depth .The maps are prepared, based on the seasonal changes and annual water level data.

Winter season groundwater level

In the winter season spatial distribution map shows that the water is moving towards northwest to southeast direction. The southern region of the study receives the shallow water table level less than 10 over an area of 24.9 sq. $\mathrm{km}$ in view of fact that, the majority of surface water bodies are located in southern part. The figure- 4 shows that the contour level falls from north zone to south zone. It represents that the southern region hasmore shallow groundwater table compare to northern region. 


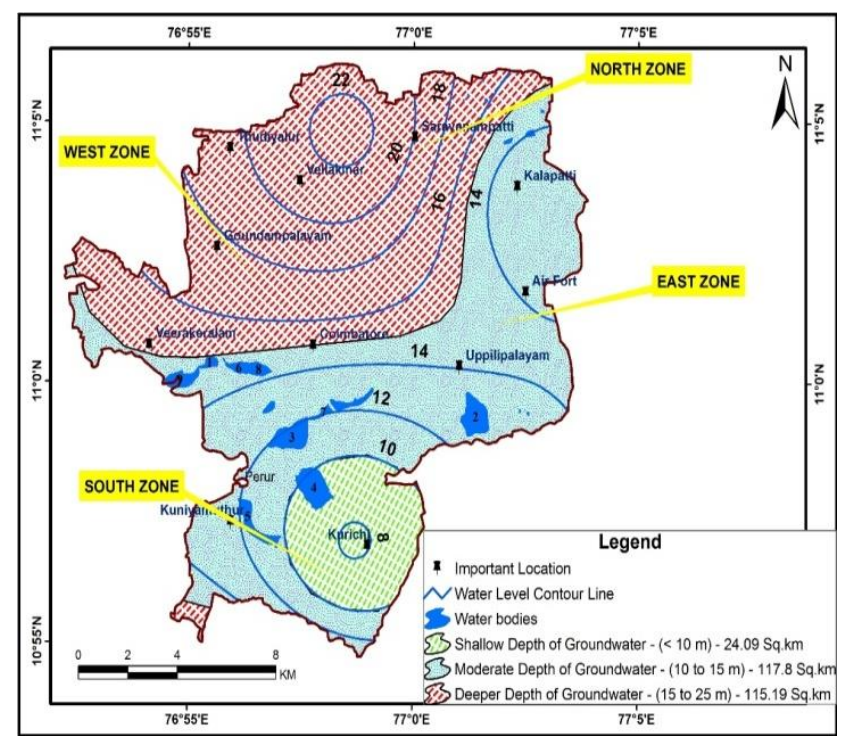

Figure-4: Winter season water level map

Summer season groundwater level

The spatial distribution for summer season map shows that the major study falls under the deeper groundwater level that occupies an area of $168.67 \mathrm{sq} . \mathrm{km}$ and moderate groundwater table level falls under an area of $86.67 \mathrm{sq} . \mathrm{km}$. The shallow water table level falls only in meager quantity. The map inferences that the water demand is high in summer season and less downpour. The figure-5 shows the spatial distribution map for summer season.

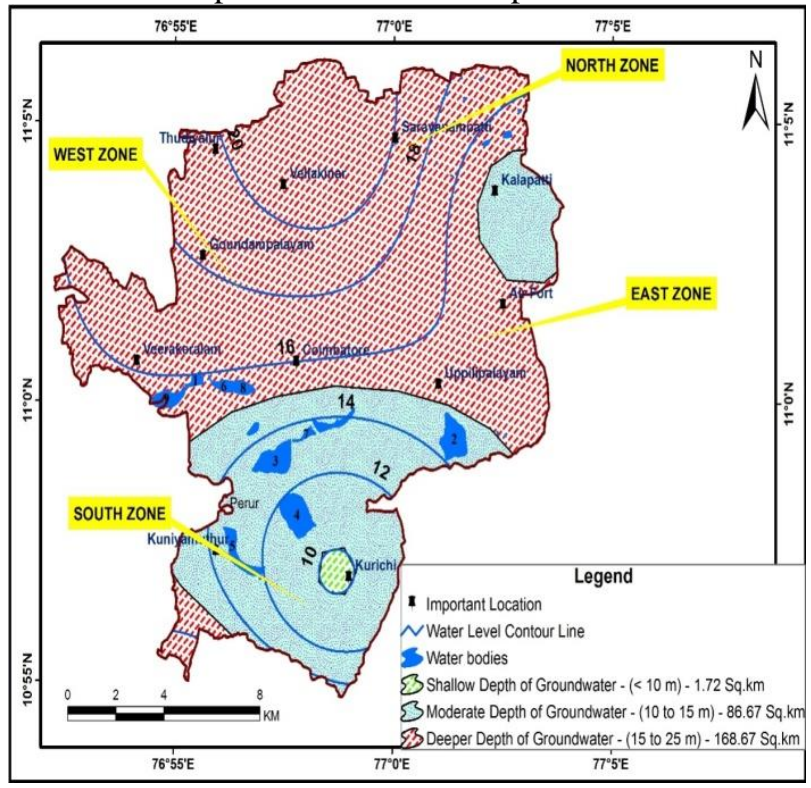

Figure-5: Summer season water level map 


\section{Southwest Monsoon season groundwater level}

This thematic map reveals that, the shallow depth of groundwater table level occupies an area of 7.86 sq. $\mathrm{km}$ and moderate depth of groundwater table covers an area of 82.09 sq.km. The figure- 6 shows that the spatial map for southwest monsoon season.

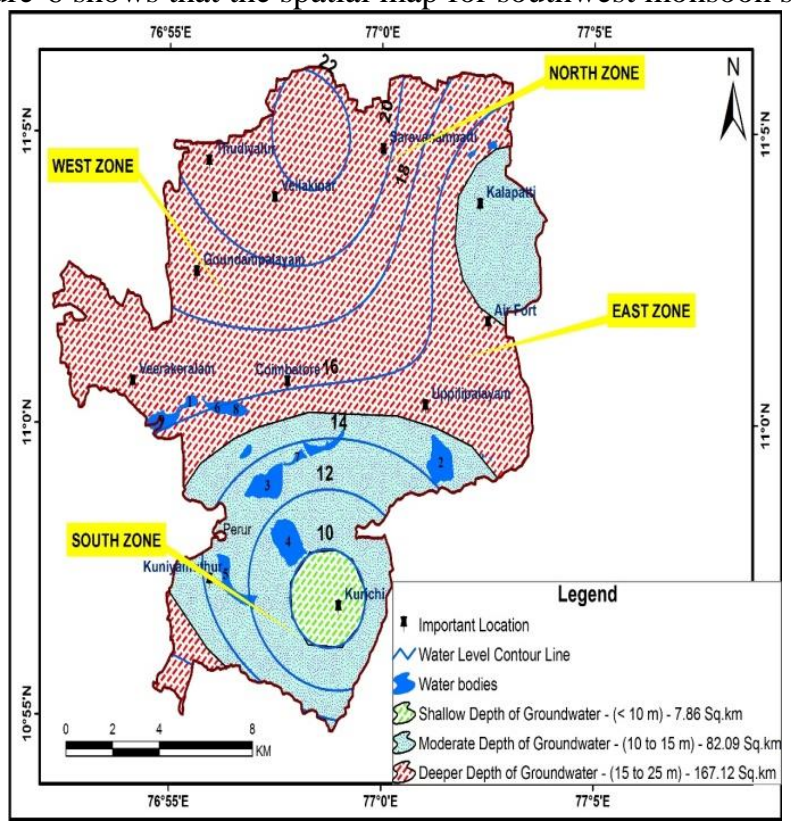

Figure-6: Southwest monsoon season water level map

Northeast Monsoon season groundwater level

The spatial distribution map reveals that the shallow water table depth occupies an area 21.44 sq.km the figure- 7 shows that the shallow water table region falls in the southern region because of two water tanks located in this region. The moderate groundwater depth region extends from south east to north east direction.

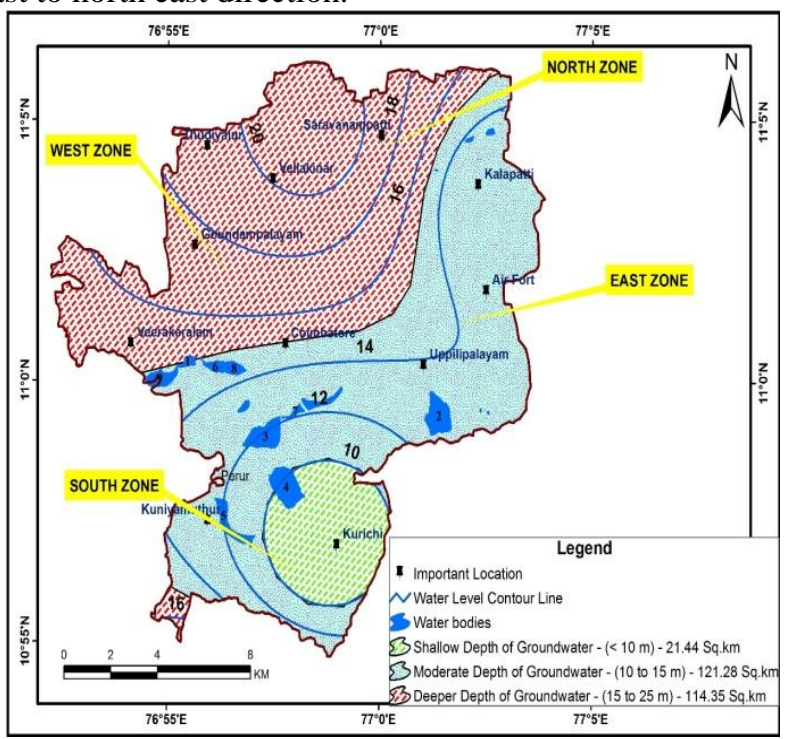


Figure-7: Northeast monsoon season water level map

Annual Mean Groundwater level

The annual mean groundwater level map discloses that the shallow groundwater table level less than $10 \mathrm{~m}$ covers an area of $14.03 \mathrm{sq} . \mathrm{km}$ and the moderate groundwater table level $10 \mathrm{~m}$ to $15 \mathrm{~m}$ extends an area of $108.92 \mathrm{sq} . \mathrm{km}$. The southern, southeast portions and Northeast portions possess the moderate to shallow groundwater table level. The figure- 8 shows the mean water table level spatial distribution map in that southern area hasshallow groundwater table level.The water resources utilization can be done effectively in this region whereas the northern region has deeper water table level, so water rejuvenation structures can be installed to augment the groundwater table level.

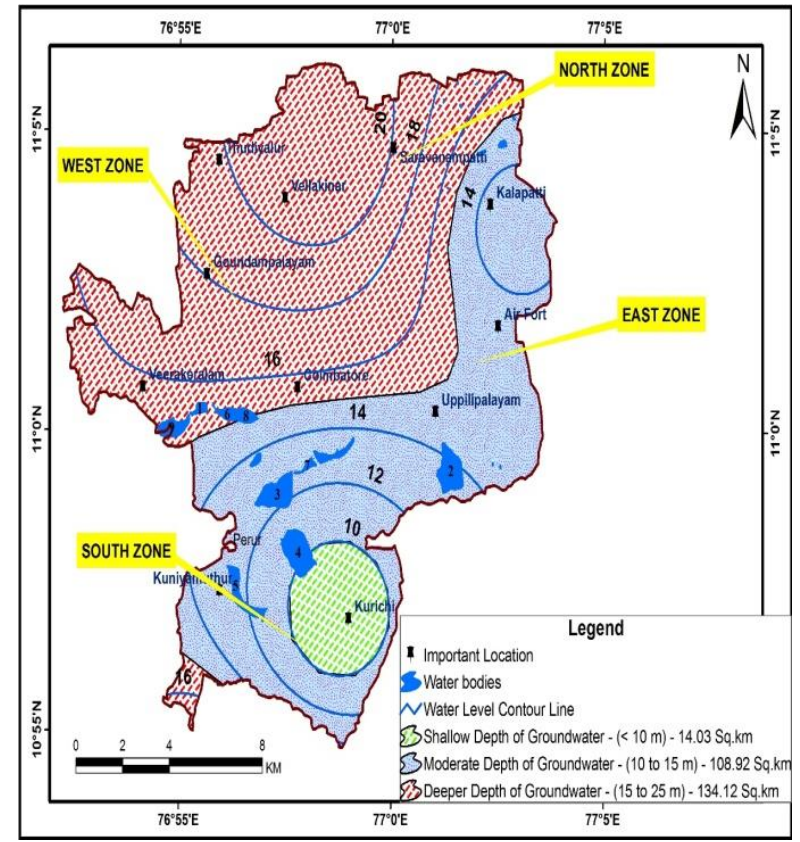

Figure-8: Annual mean water level map

Inference on Shallow Groundwater table

The seasonal spatial distribution map reveals that southern region of study area receives the shallow water table level less than $10 \mathrm{~m}$. This is due to the presence of two water tanks in this region namely kurichi and kuniymuthur lake, there will be possibility of water percolation in this region, so it will replenish the groundwater, and also precipitation will have very good interaction with the water table. This statement is exemplified here, during the winter season the shallow water table covers an area of 24.09 sq.km whereas in summer season the shallow groundwater table area shrinks to $1.72 \mathrm{sq} . \mathrm{km}$. This is because of water demand is very high in this season, next season follows the southwest and northeast monsoon .In this the northeast monsoon season receives the more rainfall, therefore the groundwater table is increased rapidly and covers an area of 21.44 sq. $\mathrm{km}$. This shows that the groundwater table depends upon the rainfall. 


\section{Results and Discussions}

The analysis on groundwater table is observed and studied with the help of seven open wells in and around the study area, also by the seasonal spatial distribution maps. In the winter season the shallow groundwater table level covers only $9.3 \%$ in the southern region whereas, others fall in moderate to deeper groundwater table, 55\% of the study area encompasses the shallow to moderate depth of groundwater table level. The rainfall phenomenon will also be responsible for the increasing trend of groundwater table; this was confirmed in rainfall analysis. It reveals that in 2011 the rainfall is higher than other years therefore the groundwater table significantly increased in the year 2012.The overall study shows that the southern region has very good groundwater table level, when compared to other zones in the study area, so groundwater pumping and utilization can be beneficially done in this region.

\section{References}

[1] G.Maheswaran, A.GeethaSelvarani, K.Elangovan, Groundwater resource exploration in Salem District, Tamilnadu using GIS and Remote sensing, Journal of Earth System Science., 125(2) 311328.

[2] K.Elangovan, Carried out characteristics of tube well water for district Erode (India), Journal of Environmental Science.,1(2)

[3] P.J.sajil Kumar, GIS-based mapping of water-level fluctuations (WLF) and its impact on groundwater in an Agrarian District in Tamilnadu, India. Environ Dev Sustain (2021).

[4] S.K.Goyal, B.S Chaudhary.Omvir Singh, Variability analysis of Groundwater levels-A GIS based case Study, Journal of the Indian Society of Remote Sensing.,38(2) (2010) 355-364.

[5] Pichaiah.S, SenthilKumar.G.R, Groundwater Level Fluctuation studies in TirupurTaluk, Tirupur District, tamilnadu, India, International Journal of emerging technologies in computational and Applied Sciences.,4(3) (2013) 258-262.

[6] K.Elangovan, P.Selvakumar, Site selection for Rainwater harvesting structures using GIS for the augmentation of Groundwater, Journal of ecology \& Natural Resources 2(3) 1-5.

[7] Semere Solomon, Friedrich Quiel, Groundwater study using remote sensing and geographic information systems(GIS) in the central highlands of Eritrea, Hydrogeology Journal.,14 (2006) 1026-1041.

[8] G.Venilla, T.Subramani, Spatial and seasonal variation of groundwater levels in Vattamalaikarai river basin, Tamilnadu, India, Indian Journal of Geo-Marine Sciences.,47(9) 2018 1749-1753.

[9] HosseinTabari, JaefarNikbakht,ShiftehSomee, Investigation of Groundwater level fluctuations in the north of Iran, Environmental earth sciences., 66 (2012) 231-243.

[10] G.vander, Kamp H Maathuis, Annual Fluctuations of Groundwater levels as a result of loading by surface moisture, Journal of Hydrology.,127(1-4) (1991) 137-152.

[11] AartiAvalkar, S.M. Yadav, A Study of Groundwater Fluctuations in Coastal Region, Global Journal of Research Analysis.,2(4) 85.

[12] Gregory UdieSikakwe, GIS-based model of groundwater occurrence using geological and hydrogeological data in Precambrian Oban massif southeastern Nigeria, Applied Water Science., 8(79) (2018).

[13] S.Samson, K.Elangovan, Delineation of Groundwater recharge potential zones in Namakkal district, Tamilnadu, India. Using remote sensing and GIS., Journal of the Indian Society of Remote Sensing 43(4) 769-778.

[14] S.P.Rajaveni, K.Brindha, L.Elango, Geological and Geomorphological controls on Groundwater occurrence in a hard rock region, 7 (2017) 1377-1389. 
[15] S.Anbazhagan, A.Jothibasu, Geoinformatics in groundwater potential mapping and sustainable development: a case study from southern India, Hydrological Sciences Journal 61 (6) 1109-1123.

[16] S. M. S. S, D. S. Vijayan, M. Anand, M. Ajona, and T. Jarin, " Biodegradation of P-nitro phenol using a novel bacterium Achromobacterdenitrifacians isolated from industrial effluent water ," Water Sci. Technol., vol. 00, no. 0, pp. 1-12, 2021, doi: 10.2166/wst.2021.354

[17] C. Nivetha, D. S. Vijayan, R. Ravishanker et al., Use of Pennywort for nitrogen and phosphate removal from sewage, Materials Today: Proceedings, https://doi.org/10.1016/j.matpr.2020.05.215

[18] M. Tholkapiyan, A.Mohan, Vijayan.D.S , "A survey of recent studieson chlorophyll variation in Indian coastal waters", IOP Conf. Series: Materials Science and Engineering 993 (2020) 012041, doi:10.1088/1757-899X/993/1/012041. 